\title{
Managing Open Innovation A Project-level Perspective
}

\author{
Bagherzadeh, Mehdi; Markovic, Stefan ; Bogers, Marcel
}

Document Version

Accepted author manuscript

Published in:

IEEE Transactions on Engineering Management

DOI:

10.1109/TEM.2019.2949714

Publication date:

2021

License

Unspecified

Citation for published version (APA):

Bagherzadeh, M., Markovic, S., \& Bogers, M. (2021). Managing Open Innovation: A Project-level Perspective. IEEE Transactions on Engineering Management, 68(1), 301-316. https://doi.org/10.1109/TEM.2019.2949714

Link to publication in CBS Research Portal

\section{General rights}

Copyright and moral rights for the publications made accessible in the public portal are retained by the authors and/or other copyright owners and it is a condition of accessing publications that users recognise and abide by the legal requirements associated with these rights.

Take down policy

If you believe that this document breaches copyright please contact us (research.lib@cbs.dk) providing details, and we will remove access to the work immediately and investigate your claim. 


\title{
Managing Open Innovation: A Project-level Perspective
} Mehdi Bagherzadeh, Stefan Markovic, and Marcel Bogers

\author{
Journal article (Accepted manuscript*)
}

\section{Please cite this article as:}

Bagherzadeh, M., Markovic, S., \& Bogers, M. (2019). Managing Open Innovation: A Project-level Perspective. IEEE Transactions on Engineering Management. https://doi.org/10.1109/TEM.2019.2949714

DOI: https://doi.org/10.1109/TEM.2019.2949714

* This version of the article has been accepted for publication and undergone full peer review but has not been through the copyediting, typesetting, pagination and proofreading process, which may lead to differences between this version and the publisher's final version AKA Version of Record.

Uploaded to CBS Research Portal: September २०२० 
Article reference: Bagherzadeh, M., Markovic, S., \& Bogers, M. (2019). Managing Open

Innovation: A Project-Level Perspective. IEEE Transactions on Engineering Management. DOI:

10.1109/TEM.2019.2949714

\section{Managing open innovation: A project-level perspective}

\section{Mehdi Bagherzadeh}

Mehdi Bagherzadeh received the Ph.D. degree in Management Sciences (Innovation Management) with distinction "Cum Laude" from ESADE Business School, Barcelona, Spain, in 2016. He is currently an Assistant Professor of Innovation Management with the Department of Strategy and Entrepreneurship and Academic Director of the MSc Entrepreneurship \& Innovation program, NEOMA Business School, Reims, France. His research has been published in academic journals, such as Journal of Management, Journal of Business Research, the IEEE Transactions on Engineering Management, and Journal of Business Ethics. His research interests include open and collaborative innovation, particularly at project level.

Email: mehdi.bagherzadeh@neoma-bs.fr

\section{Stefan Markovic}

Stefan Markovic received the Ph.D. degree in management sciences with distinction Cum Laude from ESADE Business School, Barcelona, Spain, in 2016. He is currently an Associate Professor in Marketing and Chair of the Marketing Ethics Research Cluster at the Department of Marketing, Copenhagen Business School, Frederiksberg, Denmark. He is also an Associate Editor of Business Ethics: A European Review, and Co-chair of the Special Interest Group on Branding at the European Marketing Academy Conference (EMAC). His research interests include brand management, innovation, and ethics/CSR/sustainability. His research has been published in top-tier international journals, including Journal of Business Ethics, Journal of Business Research, Industrial Marketing Management, and IEEE Transactions on Engineering Management.

Email: sm.marktg@cbs.dk

\section{Marcel Bogers}

Marcel Bogers received the Ph.D. degree in management of technology from Ecole Polytechniques Fédérale de Lausanne (Swiss Federal Institute of Technology) in 2009. He is currently a Professor of Innovation and Entrepreneurship with the Department of Food and Resources Economics, Faculty of Science, University of Copenhagen, Frederiksberg, Denmark. His research has been published in top-tier international journals in a variety of domains. His research interests relate to openness and participation in innovation and entrepreneurial processes within, outside and between organizations, and he has specifically studied issues such as open innovation, business models, family businesses, users as innovators, collaborative prototyping, improvisation, and university-industry collaboration.

Email: marcel@ifro.ku.dk

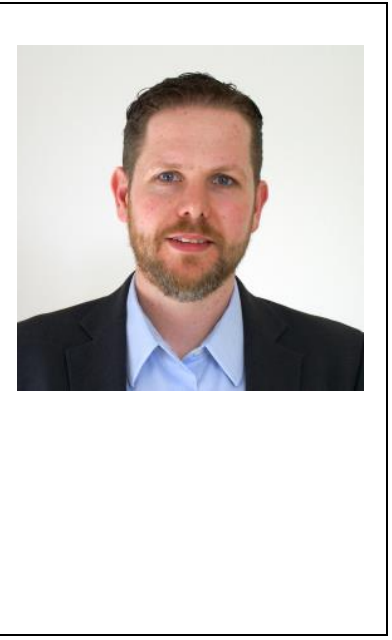




\section{ABSTRACT}

Open innovation has become a mainstream phenomenon in the current business landscape. However, despite the fact that innovation projects generally have different attributes (e.g., complexity, uncertainty), most studies on open innovation have only considered firm-level characteristics (e.g., firm size and firm openness) to determine how to manage open innovation successfully. Project-level studies on open innovation management are still scant - there are only a few conceptual and qualitative articles on the topic, and there is a lack of quantitative insights. Based on a survey designed to collect detailed data from 201 innovation projects undertaken by American firms, this article provides a quantitative cross-project analysis of how two, key innovation project attributes (i.e., complexity and uncertainty) are related to five factors for successful open innovation management: (1) openness level; (2) external partner choice; (3) open innovation mechanism choice; (4) collaboration process formalization; and (5) internal firm practices. This exploratory study contributes to the open innovation literature by highlighting the importance of micro-foundations (i.e., innovation project attributes) in successful open innovation management. This study concludes by suggesting a number of relevant project-level future research opportunities in the field of open innovation management, and some methodological recommendations on how to address such opportunities. 


\section{MANAGERIAL RELEVANCE STATEMENT}

Managers should be aware that they cannot deal with all innovation projects equally even within the same firm, because different innovation projects have different attributes (e.g., complexity, uncertainty). Innovation projects with different attributes require different managerial factors for successful open innovation management. Our study provides managers with an empirically supported framework that they can use when making early-stage decisions related to the five factors for successful open innovation management (i.e., openness level, external partner choice, open innovation mechanism choice, collaboration process formalization, and internal firm practices). Considering these factors in the early stages can also help managers to allocate the resources properly in later stages of the innovation project, and thereby foster innovation project success. For example, when facing a complex or uncertain innovation project, our framework suggests that managers should collaborate with a more diverse set of external partners. Moreover, our framework proposes that managers should focus on improving the communication with innovation project members, incentivize communication among those members, and reward those employees who acquire and share knowledge effectively.

\section{KEYWORDS}

Open innovation; project attributes; project complexity; project uncertainty; project-level variables 


\section{INTRODUCTION}

In an ever more competitive business environment, firms are increasingly transcending boundaries to improve their innovation activities by consciously using knowledge inflows and outflows [1]. In other words, firms are increasingly embracing open innovation (OI). The concept of OI has received considerable scholarly attention over the last decade [2-8], and most articles on OI have taken a firmlevel perspective [2, 3]. Firm-level studies have highlighted five factors that firms need to consider for successful OI management: (1) openness level [9, 10]; (2) external partner choice (e.g., users, suppliers, universities, competitors, entrepreneurs, and start-ups) [11, 12]; (3) OI mechanism choice (e.g., licensing agreements, alliances, innovation contests, and crowdsourcing intermediaries) [13]; (4) collaboration process formalization [14]; and (5) internal firm practices [15-17].

However, although these firm-level articles provide useful frameworks for managing OI, they fail to consider that not all innovation projects are equal, even in the same firm [18]. Instead, innovation projects generally have different attributes, such as strategic importance, complexity of innovation tasks, type of required knowledge and resources, and project uncertainty, in terms of technologies and customer preferences [18-20]. Scholars have identified project complexity and project uncertainty as the most important of these attributes [21-23]. This fact calls for a downward shift in the study of OI management from firm to project level, since neglecting project attributes may prevent full understanding of successful OI management $[18,24]$. Accordingly, West et al. [25, p. 287] argued that "neither the practice of nor the research on open innovation is limited to the level of the firm." Similarly, Antons et al. [2, p. 745] claimed that "most recent research on the hot topic of open innovation is based on a firm-level perspective and could be enriched by project-level studies."

Surprisingly, however, project-level studies on OI management are still rare [2, 3]. Only a few conceptual and qualitative studies of project-level OI management have been conducted so far (e.g., $[19,21,23,26])$, and there is a dearth of quantitative insights, which might be due to the difficulty of accessing detailed project-level OI data [24]. Among these few conceptual and qualitative projectlevel studies of OI management, Brunswicker et al. [23] use a multiple case study methodology to 
show that even the same firm can use different OI mechanisms (e.g., licensing agreements, alliances, innovation contests, and crowdsourcing intermediaries) for different innovation projects. Likewise, in a recent conceptual study, Felin and Zenger [19] argued that innovation projects with different attributes require different OI mechanisms. Similarly, in a qualitative study, Faems et al. [27] showed that the same firm uses different levels of collaboration process formalization in different collaborative innovation projects. This heterogeneity in factors for OI management across innovation projects demonstrates the importance of studying how these factors depend on project attributes, which remain under-researched [19, 28].

To address this important, under-researched topic, and the aforementioned lack of quantitative project-level studies of OI management, we provide a quantitative cross-project analysis of how two important project attributes (i.e., project complexity and project uncertainty) are related to the five factors for successful OI management (i.e., openness level, external partner choice, OI mechanism choice, collaboration process formalization, and internal firm practices). We studied 201 innovation projects undertaken by firms from the USA. Our findings highlight how project complexity and project uncertainty are related to each of the five factors, and contribute to project-level OI research. Our findings also reveal a number of avenues for future project-level research in OI management, and we present some methodological recommendations for this future research.

\section{PROJECT ATTRIBUTES AND OI MANAGEMENT}

A key stage of managing innovation projects (projects, hereafter) is the search for solutions to advance projects and help meet their objectives [22]. Not all projects, even in the same firm, are alike [18]. They have many different attributes, such as strategic importance and the complexity of the problem to be solved $[20,26]$. The problem-solving perspective suggests that different projects require different forms of solution search [22]. The literature proposes two widely established forms of solution search: directional and cognitive [29]. The directional solution search involves testing (i.e., an experiment) various solutions after their implementation to see whether they meet the needs 
of the project, and, if not, adjusting them accordingly $[22,29]$. In contrast, cognitive solution search involves a process in which the project members assess the results of potential solutions before implementing them $[22,29]$. This assessment is based on a cognitive map, which is a simple representation of the solution space, specifying the required resources (e.g., knowledge sets) and their underlying interactions for developing a solution [22, 29]. The problem solving perspective argues that each of the two forms of solution search has its own characteristics and/or needs. The key characteristic of directional solution search is that both internal and external partners can pursue trials (i.e., experiments) independently to get feedback and assess solutions [22]. On the other hand, creating an appropriate cognitive map to conduct an efficient cognitive solution search needs deep interaction and extensive knowledge exchange between project partners (both inside and outside the focal firm) to ensure that all relevant and required knowledge sets are available to all the partners involved [22]. Thus, each solution search form demands a specific managerial approach to address its characteristics and/or needs. Drawing upon the problem solving perspective, we argue that different projects need different solution search forms, and therefore an appropriate management system supporting the proper form of solution search. For example, complex projects demand a cognitive solution search involving deep interactions and extensive knowledge sharing among the involved partners. Project members must therefore select managerial factors that support the proper levels of interactions and knowledge sharing $[19,22]$. As the selection of the appropriate managerial factors depends on project attributes, research on OI management cannot assume project homogeneity [30]. Therefore, to capture the heterogeneity of project attributes, we need to consider the microfoundations of OI management (i.e., project attributes), which can provide more detailed and stable results regarding OI management than firm-level analyses.

Among the different types of project attributes (e.g., type of external knowledge required such as basicness and novelty, strategic importance, and project uncertainty in terms of technologies and customer preferences), the few existing conceptual papers on OI management (e.g., [21, 22]), together with a qualitative case study on OI management [23], have recognized two attributes (project 
complexity and project uncertainty) as the most important. Project complexity can be defined as the number of tasks, elements, and knowledge sets required to complete a project, and the degree of interdependency between them [31]. Project uncertainty refers to the extent of change in the technologies and customer preferences related to the project [32]. As previous research has considered these two project attributes to be the most important ones, in this article we analyze their roles in OI management.

OI research has argued that collaboration with external partners encompasses two key phases: formation and execution [33]. Formation refers to the initial setting (e.g., defining the problem to be solved in the project) before engaging in OI. In the execution phase, the OI activity and use of external knowledge are put into effect. The OI literature has suggested these two phases as important building blocks of OI management [33]. In this paper, we study both phases, since focusing on only one would result in a limited understanding of OI management. Scholars have identified five factors that firms need to consider in these two phases for successful OI management. Scholars have argued that managers need to consider three important factors in the formation phase: openness level (i.e., the focal firm's overall interactions with external partners in all its innovation activities); external partner choice (e.g., users, suppliers, competitors, universities, entrepreneurs, and start-ups); and OI mechanism choice (e.g., licensing agreements, alliances, innovation contests, and crowdsourcing intermediaries) $[9,12,13]$. Scholars have also argued that, in the execution phase, managers need to consider two other important factors: collaboration process formalization (i.e., organizing the firm's interactions with external partners to be able to use external knowledge effectively) [14, 34], and internal firm practices (e.g., establishing communication channels between project members and reward systems for sharing and acquiring knowledge) $[15,16,35]$. As previous, mainly firm-level OI research has pointed to the importance of these five factors for successful OI management, in this article we analyze how they are associated with project complexity and project uncertainty. The following section provides the theoretical background for the five factors. 
Openness level. Most previous studies have only studied the antecedents of firm openness (i.e., the focal firm's overall interactions with external partners in all its innovation activities). For example, Bogers et al. [9] investigated the influence of employee diversity on firm openness to external partners. Laursen and Salter [36] studied the impact of the firms' appropriation strategies (e.g., patent, trademarks, and secrecy) on firm openness. However, few studies have examined project openness (i.e., the focal firm's interactions with external partners for a particular project), and most of these are purely conceptual [21]. Among such studies, a simulation-based research of OI has shown that project complexity is likely to affect the level of project openness to external partners [21]. More specifically, Almirall and Casadesus-Masanell [21] argued that highly complex projects (i.e., when the solution depends on a large number of highly interdependent tasks and knowledge sets), require extensive project openness when a wide set of external partners are available for collaboration with the focal firm. Nickerson and Zenger [22] argued that no individual firm has all the knowledge required to find an appropriate solution when projects become more complex. Thus, a higher level of openness would give firms access to potentially relevant knowledge sets that would otherwise be very difficult to obtain, and would enhance the likelihood of finding those knowledge sets necessary to achieve an appropriate solution to specific problems [17, 37]. In a cross-industrial, survey-based study of R\&D projects funded by the Korean government, Kim et al. [38] found that when a project involves technologically uncertain tasks, it tends to be more open to outsiders. This evidence points to the possibility that, apart from being a firm-related variable, openness is also a project-related variable. Thus, the focal firms that embrace OI may not adopt the same level of openness for all their projects, and this fact emphasizes the importance of studying project openness. Project attributes may relate to project openness independently or in combination [19]. For example, as a project becomes more complex, its uncertainty may also increase, indicating that project complexity and uncertainty may influence each other, which points to an interaction effect between the two attributes on project openness. 
Even though we argue that openness is a project-related variable that depends on the two project attributes, OI-related factors specific to a firm (e.g., the firm's total investment in OI activities) may also be related to project openness [5]. For example, a firm that invests extensively in OI will provide greater support for project openness, and more of its employees will embrace OI for the sake of the project. This highlights the importance of studying the relationship between firm openness and project openness.

In this article, and following Laursen and Salter [10] and Kobarg et al. [39], we study the two key components of project openness: openness breadth and openness depth. Project openness breadth refers to the number of types of external partners a firm interacts with in a particular project [10], whereas project openness depth captures the intensity of the interactions with these different types of external partners in a particular project [10].

External partner choice. OI can involve several types of external partners, such as users, suppliers, universities, competitors, entrepreneurs, and start-ups [35, 40]. These various types of external partners can provide the firm with different kinds of knowledge [12]. For example, the knowledge developed by universities and research centers is likely to be highly original [41]. Accordingly, Cassiman et al. [20] argued that when the required knowledge is very novel, collaboration with universities and research centers is more attractive than with firms. A number of empirical articles $[11,12]$ examined firm and industry-level variables affecting external partner choice. For instance, based on a firm-level dataset, Sofka and Grimpe [12] found that the technological environment in which firms conduct their innovation activities is likely to affect their choice of external partners. More specifically, they found that a technologically advanced environment leads firms to collaborate with scientific partners, as these can provide highly novel knowledge. This suggests that when embracing OI, firms may not involve the same external partners in all their projects, and highlights the importance of investigating external partner choice at the project level. 
OI mechanism choice. To tap into the knowledge of external partners, firms can use a variety of OI mechanisms [40]. These include markets and contracts (e.g., licensing agreements), OI platforms (e.g., innovation contests and crowdsourcing intermediaries), and non-equity and equity partnerships (e.g., alliances and joint ventures) [40]. In light of the wide variety of OI mechanisms, the choice of mechanism is another important factor to consider if firms want to manage OI successfully [19]. However, little research has considered project attributes as determinants of OI mechanism choice, and most of this research is purely conceptual (e.g., [19, 26]). For example, Felin and Zenger [19] argued that partnerships, such as strategic alliances, can be an appropriate mechanism for complex projects. Similarly, Afuah and Tucci [26] suggested that project attributes can affect mechanism selection, including crowdsourcing and designated suppliers. More specifically, they proposed that crowdsourcing is less attractive for highly complex projects. Overall, firms may not apply the same mechanisms to all of their projects, and this emphasizes the importance of exploring project-level mechanism choice.

Collaboration process formalization. A recent systematic review of case studies describing inter-organizational collaboration has shown that the degree of formalization of the collaboration between a firm and its external partners is an important managerial factor that requires consideration when embracing OI [33]. Collaboration process formalization involves specifying and enforcing activities to be followed by both the firm and its external partners to jointly achieve the goals [14]. This formalization is based on specific procedures, manuals, and role distribution [14]. In an empirical study on managing OI activities using a project-level dataset from a large European multinational firm, Du et al. [18] showed that project management formalization (i.e., planning and controlling project tasks and activities in a formal way) differs across projects. Similarly, in a qualitative study, Faems et al. [27] showed that the same firm uses different levels of collaboration process formalization in different innovation projects. This indicates that the formalization level of the collaboration process is unique to each project. Therefore, firms engaging in OI may introduce 
different levels of formality to their collaboration processes in different projects. This highlights the importance of studying project-level collaboration process formalization.

Internal firm practices. Previous studies have highlighted that collaborating with external partners can create a set of managerial challenges (e.g., identifying relevant, valuable external knowledge; understanding the absorbed external knowledge; making the absorbed external knowledge available to all the firm's employees) that need to be addressed by implementing appropriate internal practices [42]. These internal practices can enable firms to better explore, assimilate, and exploit external knowledge (the three components of absorptive capacity), which is critical in any OI process [43-46]. This absorptive capacity increases the likelihood of using external knowledge successfully in the firm's different projects [44]. A conceptual article has argued that different project attributes require the adoption of different internal practices [47]. Concretely, Heiman and Nickerson [47] argued that different degrees of knowledge sharing between employees are required for different types of projects. This suggests that firms need to adapt their internal practices to support different levels of knowledge sharing among employees. Thus, firms need to adopt different internal practices for their different types of projects, and this highlights the importance of studying internal practices based on project attributes. In line with the systematic review of the literature on internal practices conducted by Foss et al. [15], we include two important internal firm practices in this study: (1) knowledge incentives (i.e., the extent to which the involved firm's employees in the project are rewarded for acquiring and sharing knowledge); and (2) internal communication (i.e., communication among project team members and between project team members and managers).

\section{METHODOLOGY}

\subsection{Data collection and sample}

An external panel company that specialized in the recruitment of target respondents and survey execution collected our data in 2016 via an online survey. The panel company distributed the survey 
we had designed to the respondents, managed respondent incentives, and encouraged their pool of panelists to take part.

The panel company sent the survey to large firms in the USA with more than 500 employees and more than $\$ 10 \mathrm{~m}$ in revenue in 2015 , operating in four industry groups: (1) finance, banking and insurance; (2) healthcare and social assistance; (3) manufacturing; and (4) retail/wholesale trade. In this population, we focused on three functional areas: (1) marketing/sales; (2) information technology/information systems; and (3) research and development (R\&D). We focused on large firms to ensure that we would find relevant projects involving external partners, as large firms usually engage in OI based on their project needs. Also, respondents from large firms are generally more knowledgeable about OI activities within firms than those in small firms [48]. To find suitable respondents with sufficient information about the projects (i.e., to minimize informant bias) [49], we only recruited full-time staff (working at least 35 hours per week) in senior managerial positions (owner/CEO, senior executive, executive, senior manager, or manager/supervisor) and with budgetary authority (for the entire company or organization, within a department or division, or within a team or group). To complete the survey, we asked respondents, based on the best of their knowledge, to select a project completed in their firm involving external partners. This increased the likelihood that respondents would select a project about which they had sufficient information. We assured respondents that we would treat their answers confidentially and only report aggregate results.

In total, we collected data on 201 OI projects undertaken in 201 firms (i.e., only one project per firm). We present the final sample characteristics in Table 1. One third of the sample represents the manufacturing industry, and $28.9 \%$ represents retail/wholesale trade. Finance, banking and insurance, and healthcare and social assistance, account for $24.4 \%$ and $13.4 \%$ of the sample respectively. In terms of company size, $25.9 \%$ of the sampled firms are very large (10000 employees or more), and 58.7\% have between 1000 and 9999 employees. Firms with 500 - 999 employees represent $15.4 \%$ of the sample. This shows that our sample is well balanced in terms of industry groups and firm size. 


\section{----- INSERT TABLE 1 ABOUT HERE -----}

\subsection{Constructs and items}

We adapted the scale items to measure all constructs from previous studies. Two OI scholars (i.e., associate university professors) and two survey development experts (i.e., one full university professor and one senior post-doc researcher) reviewed the adapted items, and we conducted a pilot test with three senior managers (one CEO and two CIOs) in large USA companies. In light of the item review and pilot test, we made a few minor changes to improve the original items. We present the constructs and the final items by which they were measured below. The respondents were asked to assess one project, which they selected, based on all the measures indicated below. For the five constructs operationalized by Likert-type measures (i.e., project complexity, project uncertainty, collaboration process formalization, knowledge incentives, and internal communication), we performed confirmatory factor analysis (CFA), using the maximum likelihood method, to assess their reliability and validity. The five-factor measurement model had acceptable fit indices (Chi-square $=$ 30.76 with $\mathrm{df}=34$; Chi-square $/ \mathrm{df}=0.91$; goodness of fit index $=0.97$; comparative fit index $=1.00$; normed fit index $=0.96 ; 90 \% \mathrm{CI}$ for root mean square error of approximation $=0-0.05 ;$ standardized root mean square residual $=0.03$ ) [50]. The standardized factor loadings of the five constructs were significant and higher than the recommended cut-off value of 0.5 (they ranged between 0.57 and 0.84 ) [51]. Moreover, the average variances extracted (AVEs) of the five constructs were higher than or very close to the acceptable threshold of 0.5 (they ranged from 0.4 to 0.7 ) [51]. These results supported the validity of the five constructs. The composite reliability (CR) values of the five constructs were greater or close to the acceptable threshold of 0.7 (they ranged from 0.54 to 0.82 ) [51]. In addition, the correlations between the measures (in the case of constructs with only two measures) were higher than the recommended cut-off value of 0.25 (they ranged from 0.38 to 0.7 ) [52], and the Cronbach alpha coefficient (in the case of the construct with more than two measures i.e., collaboration process formalization) was equal to the acceptable threshold of 0.7 [52]. These results showed sufficient reliability of the five constructs operationalized by Likert-type measures. 
To measure the construct of project complexity, we asked respondents to assess the selected project using the following two items: (1) it involved a large number of highly interdependent tasks; and (2) new tasks and interdependencies between them emerged unexpectedly (adapted from [28]). They assessed both items on a seven-point Likert scale (1, Strongly Disagree; 7, Strongly Agree). Then, we averaged the values of these two items $(\mathrm{AVE}=0.4 ; \mathrm{CR}=0.54$; the correlation between these two measures $=0.38$ with p-value $<0.001)$.

To operationalize the construct of project uncertainty, we asked respondents to assess the selected project using the following two items: (1) it was exposed to a rapidly changing technological environment; and (2) it addressed a market situation in which customers tended to look for new products all the time (adapted from [32]). They assessed both items on a seven-point Likert scale (1, Strongly Disagree; 7, Strongly Agree). Then, we averaged the values of these two items (AVE $=0.5$; $\mathrm{CR}=0.68$; correlation between the two items $=0.5$ with $\mathrm{p}$-value $<0.001)$.

To measure the construct of project openness breadth, we asked respondents to indicate which type(s) of external partners they interacted with during the selected project. We provided them with a list of five different types of external partners: (1) users; (2) suppliers; (3) competitors; (4) universities and public research organizations; and (5) entrepreneurs and start-ups (adapted from [40]). We first considered each type of external partner as a binary variable, which had value 0 if the firm did not interact with that partner, and value 1 if the firm did interact with it. We then created an aggregate measure by adding up the values of the five types of external partners. Thus, for example, if the firm interacted with users and competitors in a particular project, project openness breadth had a value of 2 .

To operationalize the construct of project openness depth, we asked respondents to indicate the approximate number of hours per week that the members of the selected project (staff in the focal firm) spent with the abovementioned five types of external partners. They responded on a four-point scale, where 1 referred to "10 hours or less," 2 to "11 to 20 hours," 3 to "21 to 30 hours," and 4 to 
"31 hours and more." We then generated a combined measure by calculating the average time spent with the five types of external partners.

To measure the construct of OI mechanism choice, we provided respondents with a list of four different types of OI mechanisms: (1) bilateral contract with an external partner (e.g., licensing contract); (2) collaborative agreement with external partners (e.g., consortia agreements and alliance partnerships); (3) innovation contest with an open call to the world for submissions or crowdsourcing intermediaries (e.g., NineSigma); and (4) corporate innovation communities managed by firms (in which participants can interact) (adapted from [40]). Respondents indicated which of these mechanisms they applied in their selected projects.

To operationalize the construct of collaboration process formalization, we asked respondents to assess the following three items in relation to their selected project: (1) we had an understandable, written sequence of activities that could be followed by internal and external partners; (2) we had a set of established documents such as procedures, manuals, etc., that guided the external and internal partners involved; and (3) external partners were informed about how their deliverables contributed to the overall project goals (adapted from [53]). They assessed all three items on a seven-point Likert scale (1, Strongly Disagree; 7, Strongly Agree). Then, we averaged the values of these three items $(\mathrm{AVE}=0.44 ; \mathrm{CR}=0.7 ;$ Cronbach alpha coefficient $=0.7)$

To operationalize the construct of knowledge incentives, we asked respondents to indicate on a seven-point Likert scale (1, Strongly Disagree; 7, Strongly Agree) to what extent they agreed with the two following items: (1) project team members' salary was linked to the ability and willingness to share knowledge within team and company, and (2) project team members' salary was linked to the willingness to improve and upgrade their skills and know-how relevant to the project (adapted from [15]). Then, we averaged the two items (AVE $=0.7 ; \mathrm{CR}=0.82$; correlation between the two items $=0.7$ with $p$-value $<0.001)$

To measure the construct of internal communication, we asked respondents to indicate on a seven-point Likert Scale (1, Strongly Disagree; 7, Strongly Agree) to what extent they agreed with 
the following two items: (1) project team members exchanged their information and skills relevant to the project with one another, and (2) there was communication between team members and the management of the company (adapted from [15]). Then, we averaged the two items (AVE $=0.6$; CR $=0.73$; correlation between the two items $=0.58$ with $\mathrm{p}$-value $<0.001)$.

\subsection{Methods}

As this study is exploratory, we conducted a set of exploratory statistical analyses using SPSS 23.0, including tabular and graphical methods (bar chart, cross-tabulation, and scatter plot), and numerical methods (correlation analysis, Chi-square test, analysis of variance - ANOVA, and two-sample t-test analysis) [54]. Moreover, to develop a set of clusters of projects involving the same types of external partners (users, suppliers, competitors, universities, entrepreneurs, and start-ups), we conducted a two-step cluster analysis (i.e., hierarchical and non-hierarchical K-means methods sequentially) to group the projects based on these external partners with which firms interact [54].

\section{DATA ANALYSIS AND RESULTS}

This section provides empirical evidence of how the two project attributes of project complexity and project uncertainty relate to the five factors for successful OI management (openness level, external partner choice, OI mechanism choice, collaboration process formalization, and internal firm practices).

Openness level. We first explored whether and how project openness (i.e., openness breadth and openness depth) relates to the two project attributes. The results of the correlation analysis (see Table 2) show a significant positive association between these two project attributes and the depth and breadth of project openness.

\section{----- INSERT TABLE 2 ABOUT HERE -----}

Next, we compared project openness between the two extreme groups of projects in terms of their attributes: the last quartile (i.e., high project complexity/uncertainty) with the first quartile (i.e., 
low project complexity/uncertainty). The results of the two-sample t-test analysis (see Fig. 1, Table 3 and 4) indicate that the breadth and the depth of project openness differ significantly depending on the complexity and uncertainty of the project. More precisely, when facing more complex projects, or more uncertain technologies and customer preferences related to the project, firms tend to interact with a more diverse set of external partners (i.e., increased breadth of openness) and spend more time with them (i.e., increased depth of openness) during the project. This shows that the two key project attributes (complexity and uncertainty) are related to project openness. Thus, the specific attributes of each project are critical contingencies for both the breadth and depth of project openness.

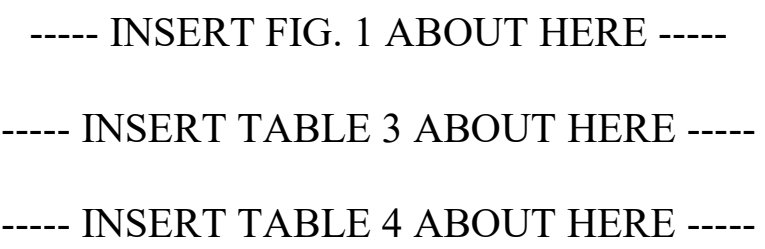

Thus far, we have explored the relationship of project complexity and project uncertainty to project openness independently. However, these may also be related to project openness in combination. The two project attributes were correlated (correlation coefficient $=0.567$ with $\mathrm{p}$-value $<0.001$ ), indicating that they influence each other. To explore the interaction effect between the two project attributes on project openness, we plotted project complexity against the breadth and the depth of project openness for low and high levels of project uncertainty.

\section{----- INSERT FIG. 2 ABOUT HERE -----}

Our results show that the association between project complexity and the breadth and the depth of project openness depends on project uncertainty (see Fig. 2). The results indicate that for more complex projects, firms tend to involve a more diverse set of external partners, and that this tendency becomes stronger when the project is more uncertain. Our findings also show no relationship between project complexity and project openness depth when the project uncertainty is low. However, for more complex projcets, firms tend to spend more time with external partners when the project uncertainty is high. This indicates that project uncertainty strengthens the relationship between project 
complexity and project openness. Thus, project complexity and project uncertainty are not only related to project openness separately, but also through their interaction.

We also assessed the relationship between the firm's total investment in OI activites (a proxy for firm openness) and project openness. We asked respondents to distribute 100 points to indicate how they allocated their total R\&D budget between OI activities and internal R\&D. The results show a significant and positive correlation between the firm's total investment in OI and both project openness breadth (correlation coefficient $=0.372$ with p-value $<0.001$ ) and depth (correlation coefficient $=0.161$ with $\mathrm{p}$-value $=0.023$ )

External partner choice. We then explored whether and how the two project attributes (complexity and uncertainty) are related to the firm's choice of external partners for the project. To do so, we first developed a set of homogeneous clusters, showing the firm's preference for a specific type of external project partner. We conducted a hierarchical cluster analysis based on the squared Euclidean distance measure and Ward's method, as this method generates the most homogenous results within a cluster and heterogonous results across clusters [54]. According to the agglomeration coefficients, we selected three cluster solutions (i.e., three-cluster, four-cluster, and five-cluster solutions) as cluster seeds for the non-hierarchical K-means method [55]. We used the Kappa test to check the interrater reliability of these three cluster solutions achieved via the hierarchical and nonhierarchical K-means method. The four-cluster solution provided the highest consistency between the two methods (Kappa coefficient $=0.253$ with $p$-value $<0.001$ ). We thus selected the four-cluster solution. We present the average time spent on the project with different types of external partners for each cluster in Table 5. We checked the validity of the four-cluster solution by conducting the ANOVA test and multiple two-sample t-tests $[55,56]$. The results show that the four clusters differ significantly in terms of time spent with external partners. In cluster 1, firms interacted extensively with all types of external partners to create an ecosystem around the project. In cluster 2, firms preferred to interact more with competitors, universities, entrepreneurs, and startups (i.e., horizontal OI) rather than with users and suppliers (i.e., vertical OI). In cluster 3, firms spent more time on their 
projects with users and suppliers (i.e., vertical OI) than with other types of external partners (i.e., horizontal OI). In cluster 4, firms interacted less with external partners than in the other three clusters. These cluster solutions show the different external partner choices firms made.

\section{----- INSERT TABLE 5 ABOUT HERE -----}

We then used these four clusters and applied the Chi-square test to explore whether and how the two project attributes of complexity and uncertainty relate to external partner choice. We present an overview of our results in Table 6 , showing that external partner choice differs significantly between projects that have high or low complexity (Chi-square $=23.962$, p-value $<0.001)$ and uncertainty $($ Chi-square $=12.771, \mathrm{p}$-value $=0.005)$. This indicates that the two project attributes are related to external partner choice.

\section{----- INSERT TABLE 6 ABOUT HERE -----}

More precisely, for projects with high levels of complexity or uncertainty, firms are likely to create an ecosystem by engaging in both horizontal and vertical OI (cluster 1) or only in horizontal OI by interacting with competitors, universities, entrepreneurs, and start-ups (cluster 2). In contrast, for projects with low levels of complexity, firms are more likely to engage in vertical OI by interacting with users and suppliers (cluster 3). In addition, our results show no relationship between project uncertainty and vertical OI (i.e., interacting with users and suppliers) (cluster 3), as the observed and expected frequencies are almost the same. We also checked the relationships between the two project attributes and external partner choice by conducting the ANOVA test and multiple two-sample t-tests (see Table 7). Although clusters 2 and 3 were not statistically significant in terms of the two project attributes, the general pattern of relationships is consistent with the results of the Chi-square test. Thus, our exploration suggests that firms prefer to interact with different types of external partners depending on project complexity and uncertainty. This shows that project attributes are important factors in explaining the firm's choice of external partners.

\section{----- INSERT TABLE 7 ABOUT HERE -----}

OI mechanism choice. We then explored whether firms prefer to apply traditional OI mechanisms, such as bilateral contracts (e.g., licensing contracts), corporate innovation communities 
or collaborative agreements with external partners (e.g., consortia agreements and alliance partnerships), or modern mechanisms, such as innovation contests or crowdsourcing intermediaries (see Fig. 3).

\section{----- INSERT FIG. 3 ABOUT HERE -----}

Previous studies often assume that firms only use one OI mechanism per project [19]. However, our exploration reveals that $70 \%$ of projects use a mixture of different OI mechanisms (see Fig. 4). Moreover, we found a significant positive relationship between the diversity of mechanisms used and both project complexity (correlation coefficient $=0.149, \mathrm{p}$-value $=0.036$ ) and project uncertainty (correlation coefficient $=0.131, \mathrm{p}$-value $\left.=0.065^{1}\right)($ see Table 2$)$. This indicates that for more complex or uncertain projects, firms tend to apply a broader set of OI mechanisms.

\section{----- INSERT FIG. 4 ABOUT HERE -----}

In addition, we used the two-sample t-test to explore whether firms prefer to apply different OI mechanisms for different types of projects. Our results showed that firms are more likely to adopt modern mechanisms, such as innovation contests or crowdsourcing intermediaries (t-value $=-2.042$, $\mathrm{p}$-value $=0.043)$, and corporate innovation communities $(\mathrm{t}$-value $=-1.825, \mathrm{p}$-value $=0.07)$ for complex projects. Moreover, they tend to use these modern mechanisms $(\mathrm{t}$-value $=-2.105, \mathrm{p}$-value $=$ $0.037)$, along with corporate innovation communities $(\mathrm{t}$-value $=-2.416$, $\mathrm{p}$-value $=0.017)$ for uncertain projects (see Table 8). These findings indicate that the OI mechanism choice is contingent upon the two project attributes of complexity and uncertainty.

\section{----- INSERT TABLE 8 ABOUT HERE -----}

Collaboration process formalization. We then explored whether and how the two project attributes are related to collaboration process formalization. We found that both project complexity $($ correlation coefficient $=0.441, \mathrm{p}$-value $<0.001)$ and project uncertainty $($ correlation coefficient $=$ 0.481, p-value $<0.001$ ) are positively related to collaboration process formalization (see Table 2). Similarly, two-sample t-test results showed that the level of collaboration process formalization

\footnotetext{
${ }^{1}$ In this paper, we consider p-values lower than 0.1 as significant.
} 
differs significantly with project complexity and uncertainty (see Fig. 5, Table 3 and 4). This means that for more complex or uncertain projects, firms tend to make the collaboration process more formal. As a result, collaboration process formalization is a project-level variable, and the two project attributes are critical contingencies for the level of formalization.

----- INSERT FIG. 5 ABOUT HERE -----

Internal firm practices. Finally, we explored whether and how the two project attributes are related to internal firm practices (i.e., knowledge incentives and internal communication). The correlation analysis (see Table 2) and the two-sample t-test results indicate that project complexity and project uncertainty are positively related to knowledge incentives and internal communication (see Fig. 6, Tables 3 and 4). This means that more complex or uncertain projects tend to reward employees more for acquiring and sharing knowledge, and project team members are also likely to communicate more among themselves and with managers.

----- INSERT FIG. 6 ABOUT HERE -----

\section{DISCUSSION AND CONCLUSION}

\subsection{Theoretical contributions}

In light of the problem-solving perspective [19, 22], projects with different attributes (e.g., complexity, uncertainty) require different managerial factors for successful OI management. To capture this project attribute heterogeneity and its effect on OI management, there is a need to shift the level of analysis from the firm to the project level. Our project-level study reveals that the five managerial factors for successful OI management are contingent on the two project attributes of project complexity and uncertainty. Our exploratory study contributes to the OI literature by highlighting the importance of micro-foundations (i.e., project attributes) in successful OI management. The micro-foundations of OI provide more detailed and stable explanations than earlier firm-level analyses, as they capture project heterogeneity. Thus, our study addresses the calls by Antons et al. [2] and West and Bogers [4] to conduct further studies in the field of OI based on project- 
level analysis. Below, we discuss how our quantitative evidence contributes to the literature with regard to each of the five managerial factors for successful OI management.

Openness level. Our findings on the interaction between the two project attributes (project complexity and project uncertainty) indicate that they are related to project openness not only separately but also in combination. This implies that simply studying the effect of project attributes separately, without considering their joint effect, may prevent full understanding of the role of project attributes in project openness. Moreover, the positive correlation between firm openness and project openness that we found implies that examining the impact of firm characteristics or project attributes separately, without considering the interaction between them, may prevent full understanding of the association between project attributes and project openness. These findings contribute to the literature on the antecedents of project openness [9, 21], and address the call by Bogers et al. [9] for further study in this area.

External partner choice. Our findings show that firms usually work on their projects with more than one type of external partner, and that project attributes are related to the selection of external partners. This contributes to the literature on OI $[35,57]$ by pointing out the suitability of building a portfolio approach to OI and collaborating with a mix of different external partners simultaneously. In addition, it builds empirically on the research by Ind et al. [58] on the collaboration between multiple types of external partners in innovation processes. Moreover, our findings indicate that the firm's decision to engage in either horizontal OI (i.e., interaction with competitors, universities, entrepreneurs, and start-ups) or vertical OI (i.e., interaction with users and suppliers) is contingent on project attributes. This contributes to the literature on external partner choice $[11,12]$ by showing that project attributes are related to external partner choice. In particular, our results complement the work of Cassiman et al. [20] by showing that project complexity and uncertainty, in addition to the novelty of knowledge required for the project, can drive collaboration with scientific partners. 
OI mechanism choice. Our empirical investigation reveals that most firms use more than one OI mechanism in their projects. Some recently published conceptual papers have argued that firms generally collaborate with external partners in their projects via a single OI mechanism $[19,26]$. Our findings contribute to this body of literature by suggesting that adopting multiple OI mechanisms simultaneously (i.e., a portfolio of OI mechanisms) can be more effective. In addition, our empirical exploration contributes to the literature by showing how project attributes drive mechanism choice [19].

Collaboration process formalization. Our findings show that firms tend to formalize the collaboration process when interacting with external partners in their projects. However, whilst previous research has studied the role of collaboration process formalization in innovation activities, it has typically examined this effect in the context of internal firm processes (e.g., formalization of collaboration between the firm's different business units) [59]. Our study thus contributes to this body of literature by showing that formalization needs to be considered when studying collaboration processes with external partners, instead of exclusively focusing on internal firm processes. Our findings also show that the two project attributes are related to the level of collaboration process formalization, which indicates that collaboration process formalization is a project-specific concept. This contributes to the literature by highlighting the importance of considering projects attributes when studying collaboration process formalization in OI projects.

Internal firm practices. Our empirical exploration shows that firms establish internal organizational practices, such as knowledge incentives, for employees to ensure that knowledge is acquired and shared throughout the course of the projects. A wide body of literature has focused on studying how firms should collaborate with external partners [60, 61], and Foss et al. [15] proposed internal organizational practices as a crucial factor in such collaboration. Our study contributes to this research by emphasizing the importance of studying internal practices based on project attributes, as firms are likely to adopt different internal practices for different types of projects. 
Overall, our study contributes to the OI literature, by studying the phenomenon at project level, and by providing quantitative evidence that two important project attributes (project complexity and project uncertainty) are related to the five factors for successful OI management (openness level, external partner choice, OI mechanism choice, collaboration process formalization, and internal firm practices) which were previously identified by firm-level research.

\subsection{Implications for managers and policymakers}

Our research has several implications for managers and policymakers. As project attributes (complexity and uncertainty) are critical to the five key managerial factors in OI activities, managers should consider them when making decisions in both the formation and the execution phases of OI. This study provides an empirically supported framework for early-stage management decisions related to the five managerial factors (openness level, external partner choice, OI mechanism choice, collaboration process formalization, and internal firm practices), which are important for resource allocation in later stages of the project and for its success. For example, when managers are dealing with complex or uncertain projects (with regard to technologies and customer preferences), our framework suggests that they should involve a more diverse set of external partners. In terms of internal practices, they should give employees more rewards for acquiring and sharing knowledge and improve communication among project members and between project members and top managers.

Although our exploratory study is at a lower level than the focus of policymakers (i.e., industry and country levels), our findings have implications for policymakers making decisions about OI that relate to broader societal challenges, such as climate, food, water, energy, and health. As policymakers often address these challenges via projects with different levels of complexity and uncertainty, our project-level findings can help them to decide on the managerial factors that they may use. 


\subsection{Limitations and future research}

Notwithstanding its theoretical contributions, this study has some limitations. First, as the sample only comprises OI projects undertaken by USA firms, the external validity of our findings is a concern. Future research should replicate this study in other countries with prominent contextual differences (e.g., national innovation system, culture of openness to external partners), such as China or other Eastern countries. This is an important avenue for future research, because projects in different contexts are likely to be managed differently $[5,62]$. Second, even though we believe that the four industry groups selected for this study are the most important and relevant industries for the study of OI [40], our findings face a second threat to external validity, as OI project management can depend on the industry in which the projects take place $[62,63]$. Therefore, future research could replicate our study in other industries. Third, since the project attributes are related to the nature of the project, and all five managerial decisions are made after defining the project, our exploratory study based on correlation analysis provides valuable empirical insights on the relationship between the two project attributes and the five managerial factors. However, to ensure that this relationship is not confounded by other factors, future studies could advance our exploratory analysis by controlling for a set of firm- and project-level variables related to the five managerial factors. Fourth, this research only focuses on two project attributes (project complexity and uncertainty). Despite the fact that previous studies on OI have recognized these two project attributes as the most important [21-23], future research should explore other attributes related to OI management and their relative importance. Fifth, even though we cover a wide range of important types of external partners (i.e., users, suppliers, competitors, universities, entrepreneurs, and start-ups), future studies could complement our findings by considering other types of external partners. In particular, non-users and the unknown crowd can be a rich source of information for generating new ideas and project solutions [64-71]. In particular, studying the unknown crowd would be important to understand how crowdsourcing is related to external partner choice. Innovation contests and crowdsourcing intermediaries can be helpful when the focal firm needs to find relevant partners from the crowd they 
do not know (i.e., when the focal firm does not know who can be helpful or is not sure about who has the best solution) [19]. Sixth, as the data for each project were collected from a single respondent, this study is subject to common method variance (CMV). However, most of the measures in our study were quite objective, reducing the probability of overestimation or underestimation of the variables. Nevertheless, future research should address this concern by using a multi-source approach for data collection (i.e., collecting data on the project attributes and the managerial factors from two respondents). Finally, as the data were only collected via surveys, mono-method bias is an issue. Thus, future research should supplement these surveys with other data collection techniques, both qualitative and quantitative.

Apart from addressing the limitations of this study, our empirical exploration has also led to a number of interesting project-level future research opportunities in relation to the five factors for successful OI management. Below, we provide more concrete future research avenues with regard to these five factors.

Openness level and external partner choice. As for openness level, future studies should explore how the cross-level interaction between project attributes and higher-level factors (e.g., industry and firm levels) are related to the breadth and the depth of project openness. As collaborating with various external partners with different characteristics (i.e., portfolio approach) can create complex relationships between the focal firm and its external partners, future research could study how firms can create an effective portfolio of external partners for their OI projects, and how project attributes are related to the creation of an optimal portfolio. Future research could also study whether and how interacting with a more or fewer partners of one specific type (e.g., single or multiple suppliers) is related to the creation of such a portfolio for OI projects. In addition, future research could explore how project attributes and the interaction between different project attributes are related to the nature of such a portfolio in terms of horizontal versus vertical openness or market-based versus science-based partnerships [18]. 
OI mechanism choice. As the selection of appropriate OI mechanisms has proved to be of crucial importance in OI management [19], future studies could explore how to apply different OI mechanisms over time in relation to different project attributes. Namely, is there a preferred sequence of applying different OI mechanisms, and how do project attributes affect this sequence? As firms involve external partners at various stages of their innovation processes (e.g., ideation, development, launch) $[62,72]$, future research should examine the relationship between OI mechanisms and the different innovation stages. This is an important future research opportunity, because each innovation stage is characterized by different knowledge needs, and thus the processes of knowledge exploration and exploitation may differ $[73,74]$. Future research in this area could also explore why firms prefer to apply more modern OI mechanisms (such as innovation contests or crowdsourcing intermediaries), despite knowing the well-established benefits of traditional OI mechanisms (such as alliances and contracts). Moreover, it would be relevant to enhance understanding of the best way to design the governance (e.g., incentive systems, communication channels, and intellectual property rights) of each OI mechanism to ensure successful collaboration with external partners.

Collaboration process formalization. As there appears to be a paradox between introducing formalization into the collaboration process and the importance of informality and trust-based relationships between partners [75], future research should examine whether successful OI projects combine both collaboration process formality and informality, and how firms can manage this potential tension. It would also be relevant to investigate the impact of project attributes and the interaction between them on the level of collaboration process formalization.

Internal firm practices. As our study has only focused on two internal firm practices (knowledge incentives and internal communication), future research should explore other internal firm practices that might influence a firm's absorptive capacity (i.e., exploration, assimilation, and exploitation), which is crucial in OI management. For instance, it would be relevant to investigate how human resource management practices, such as recruitment, and training and retention, should be designed based on project attributes. Future studies may also investigate further how project 
attributes, higher-level factors, and the interaction between them are related to the adoption of such practices.

Apart from addressing these interesting research areas related to the relationships between project attributes and the five managerial factors, future research could also study how the five managerial factors are interrelated. In particular, studying the relationship between the managerial factors in the formation and execution project phases would be both conceptually and empirically interesting [33]. For example, the level of collaboration process formalization may be contingent on the nature of external partners [18] and OI mechanisms [19], as each partner and mechanism has specific characteristics. Similarly, openness level can be related to both knowledge incentives and internal communication [15]. Moreover, how does project openness relate to collaboration process formalization and internal firm practices? Is there a preferred level of collaboration process formalization for each type of external partner and OI mechanism?

Finally, future research could advance our findings by studying OI management in the context of broader societal challenges [76-78]. Some of these challenges include climate, food, water, health, wellbeing, and energy. The UN Division for Sustainable Development Goals (DSDG) has highlighted the importance of addressing these challenges, as are becoming more urgent every day ${ }^{2}$. Addressing these challenges requires a collaborative approach to better understand the complexity and uncertainty of possible solutions, and thus OI can be helpful [78]. Future research could study how OI activities could help to find relevant solutions for these challenges.

Having proposed several avenues for future research in the field of OI highlighted by our findings, we also present some methodological suggestions to conduct such research. First, as exploring and understanding relevant project attributes and internal firm practices requires rich data from projects with external partners, we recommend adopting the multiple case study methodology [79]. This methodology would be especially useful for understanding in-depth the particularities of each project.

\footnotetext{
${ }^{2}$ https://sustainabledevelopment.un.org/?menu=1300, retrieved July 2019.
} 
Second, to study whether firms apply different OI mechanisms in either one particular order or in different sequences, we suggest using sequence analysis methods. These methods attempt to ascertain whether outcomes related to a series of activities or events occur in a particular order [80]. These methods would also be very valuable in exploring sequences of the OI mechanisms proposed in this article, and in studying why such sequences exist based on project attributes [81].

Third, our suggestion of adopting a portfolio approach to the selection of external partners and OI mechanisms points toward the use of configurational approaches to study key managerial factors in OI. Correlational-based methods, such as regression analysis, present limitations and difficulties for studying configurations and combinations of variables (i.e., how different external partners or OI mechanisms can be combined in a project). To avoid these limitations, we suggest that future studies apply the Qualitative Comparative Analysis (QCA) method [82, 83]. The QCA method, as a set-theoretic method using Boolean algebra, analyzes and determines the different combinations of variables that can result in a certain outcome. Thus, the QCA method can be very helpful in predicting which portfolio of external partners or OI mechanisms discussed in our study firms are more likely to create based on project attributes.

Finally, to examine the cross-level interaction between project attributes and higher-level factors (e.g., industry or firm levels), regression-based multilevel modeling can be useful [84]. However, using regression analysis for three-way interactions or more can create difficulties with regard to execution, statistical power, and interpretation [82]. To avoid these difficulties, we suggest future studies should use the QCA method to examine multi-way interaction effects in this area. 


\section{REFERENCES}

[1] H. Chesbrough, Open innovation: The new imperative for creating and profiting from technology. Brighton, MA, USA: Harvard Business Press, 2003.

[2] D. Antons, R. Kleer, and T. O. Salge, "Mapping the Topic landscape of JPIM, 1984-2013: In search of hidden structures and development trajectories," Journal of Product Innovation Management, vol. 33, no. 6, pp. 726-749, 2016.

[3] K. Randhawa, R. Wilden, and J. Hohberger, "A bibliometric review of open innovation: Setting a research agenda," Journal of Product Innovation Management, vol. 33, no. 6, pp. 750-772, 2016.

[4] J. West and M. Bogers, "Open innovation: current status and research opportunities," Innovation, vol. 19, no. 1, pp. 43-50, 2017.

[5] M. Bogers, A.-K. Zobel, A. Afuah, E. Almirall, S. Brunswicker, L. Dahlander, et al., "The open innovation research landscape: Established perspectives and emerging themes across different levels of analysis," Industry and Innovation, vol. 24, no. 1, pp. 8-40, 2017.

[6] J. West and M. Bogers, "Leveraging External Sources of Innovation: A Review of Research on Open Innovation," Journal of Product Innovation Management, vol. 31, no. 4, pp. 814$831,2014$.

[7] R. Teplov, E. Albats, and D. Podmetina, "What Does Open Innovation Mean? Business Versus Academic Perceptions," International Journal of Innovation Management, vol. 23, no. 1, pp. 1950002-1-33, 2019.

[8] V. Nestle, F. A. Täube, S. Heidenreich, and M. Bogers, "Establishing open innovation culture in cluster initiatives: The role of trust and information asymmetry," Technological Forecasting and Social Change, vol. 146, pp. 563-572, 2019.

[9] M. Bogers, N. J. Foss, and J. Lyngsie, "The "human side" of open innovation: The role of employee diversity in firm-level openness," Research Policy, vol. 47, no. 1, pp. 218-231, 2018. 
[10] K. Laursen and A. Salter, "Open for innovation: the role of openness in explaining innovation performance among UK manufacturing firms," Strategic Management Journal, vol. 27, no. 2, pp. 131-150, 2006.

[11] K. Laursen and A. Salter, "Searching high and low: what types of firms use universities as a source of innovation?," Research Policy, vol. 33, no. 8, pp. 1201-1215, 2004.

[12] W. Sofka and C. Grimpe, "Specialized search and innovation performance-evidence across Europe," R\&d Management, vol. 40, no. 3, pp. 310-323, 2010.

[13] R. Veugelers and B. Cassiman, "Make and buy in innovation strategies: evidence from Belgian manufacturing firms," Research Policy, vol. 28, no. 1, pp. 63-80, 1999.

[14] P. W. Vlaar, F. A. Van Den Bosch, and H. W. Volberda, "Towards a dialectic perspective on formalization in interorganizational relationships: How alliance managers capitalize on the duality inherent in contracts, rules and procedures," Organization Studies, vol. 28, no. 4, pp. 437-466, 2007.

[15] N. J. Foss, K. Laursen, and T. Pedersen, "Linking customer interaction and innovation: the mediating role of new organizational practices," Organization Science, vol. 22, no. 4, pp. 980999, 2011.

[16] N. Lakemond, L. Bengtsson, K. Laursen, and F. Tell, "Match and manage: the use of knowledge matching and project management to integrate knowledge in collaborative inbound open innovation," Industrial and Corporate Change, vol. 25, no. 2, pp. 333-352, 2016.

[17] M. Bagherzadeh, S. Markovic, J. Cheng, and W. Vanhaverbeke, "How Does Outside-In Open Innovation Influence Innovation Performance? Analyzing the Mediating Roles of Knowledge Sharing and Innovation Strategy," IEEE Transactions on Engineering Management, 2019. DOI:10.1109/TEM.2018.2889538.6.

[18] J. Du, B. Leten, and W. Vanhaverbeke, "Managing open innovation projects with sciencebased and market-based partners," Research Policy, vol. 43, no. 5, pp. 828-840, 2014. 
[19] T. Felin and T. R. Zenger, "Closed or open innovation? Problem solving and the governance choice," Research Policy, vol. 43, no. 5, pp. 914-925, 2014.

[20] B. Cassiman, M. C. Di Guardo, and G. Valentini, "Organizing links with science: Cooperate or contract?: A project-level analysis," Research Policy, vol. 39, no. 7, pp. 882-892, 2010.

[21] E. Almirall and R. Casadesus-Masanell, "Open versus closed innovation: A model of discovery and divergence," Academy of Management Review, vol. 35, no. 1, pp. 27-47, 2010.

[22] J. A. Nickerson and T. R. Zenger, "A knowledge-based theory of the firm-The problemsolving perspective," Organization Science, vol. 15, no. 6, pp. 617-632, 2004.

[23] S. Brunswicker, M. Bagherzadeh, A. Lamb, R. Narsalay, and Y. Jing, "Managing Open Innovation Projects with Impact," Whitepaper Series, July. SSRN. https://ssrn.com/abstract=2821203, 2016.

[24] J. West, A. Salter, W. Vanhaverbeke, and H. Chesbrough, "Open innovation: The next decade," Research Policy, vol. 43, no. 5, pp. 805-811, 2014.

[25] J. West, W. Vanhaverbeke, and H. Chesbrough, "Open innovation: a research agenda," in Open innovation: Researching a new paradigm, Chesbrough, H., Vanhaverbeke, W., and West, J., Eds. Oxford, U.K.: Oxford University Press, 2006, pp. 285-307.

[26] A. Afuah and C. L. Tucci, "Crowdsourcing as a solution to distant search," Academy of Management Review, vol. 37, no. 3, pp. 355-375, 2012.

[27] D. Faems, M. Janssens, A. Madhok, and B. Van Looy, "Toward an integrative perspective on alliance governance: Connecting contract design, trust dynamics, and contract application," Academy of Management Journal, vol. 51, no. 6, pp. 1053-1078, 2008.

[28] M. Bagherzadeh Niri, "Governance of Inter-Organizational Collaborations When Engaged in Open Innovation," PhD dissertation Published Thesis, Universitat Ramon Llull, 2016.

[29] G. Gavetti and D. Levinthal, "Looking forward and looking backward: Cognitive and experiential search," Administrative Science Quarterly, vol. 45, no. 1, pp. 113-137, 2000. 
[30] T. Felin, N. J. Foss, and R. E. Ployhart, "The microfoundations movement in strategy and organization theory," The Academy of Management Annals, vol. 9, no. 1, pp. 575-632, 2015.

[31] R. Fernandes and H. A. Simon, "A study of how individuals solve complex and ill-structured problems," Policy Sciences, vol. 32, no. 3, pp. 225-245, 1999.

[32] A. E. Akgün, G. S. Lynn, and J. C. Byrne, "Antecedents and consequences of unlearning in new product development teams," Journal of Product Innovation Management, vol. 23, no. 1, pp. 73-88, 2006.

[33] A. Majchrzak, S. L. Jarvenpaa, and M. Bagherzadeh, "A review of interorganizational collaboration dynamics," Journal of Management, vol. 41, no. 5, pp. 1338-1360, 2015.

[34] M. Bagherzadeh and S. Brunswicker, "The Role of Behavioral Control," in Decision Making in Behavioral Strategy, Das, T. K., ed. Charlotte, USA.: Information Age Publishing (IAP), 2016, pp. 99-119.

[35] S. Markovic and M. Bagherzadeh, "How does breadth of external stakeholder co-creation influence innovation performance? Analyzing the mediating roles of knowledge sharing and product innovation," Journal of Business Research, vol. 88, pp. 173-186, 2018.

[36] K. Laursen and A. J. Salter, "The paradox of openness: Appropriability, external search and collaboration," Research Policy, vol. 43, no. 5, pp. 867-878, 2014.

[37] Y.-C. Wu, B.-W. Lin, and C.-J. Chen, "How do internal openness and external openness affect innovation capabilities and firm performance?," IEEE Transactions on Engineering Management, vol. 60, no. 4, pp. 704-716, 2013.

[38] N. Kim, D. J. Kim, and S. Lee, "Antecedents of open innovation at the project level: empirical analysis of Korean firms," $R \& D$ Management, vol. 45, no. 5, pp. 411-439, 2015.

[39] S. Kobarg, J. Stumpf-Wollersheim, and I. M. Welpe, "More is not always better: Effects of collaboration breadth and depth on radical and incremental innovation performance at the project level," Research Policy, vol. 48, no. 1, pp. 1-10, 2019. 
[40] H. Chesbrough and S. Brunswicker, "A Fad or a Phenomenon?: The Adoption of Open Innovation Practices in Large Firms," Research-Technology Management, vol. 57, no. 2, pp. 16-25, 2014.

[41] W. M. Cohen, R. R. Nelson, and J. P. Walsh, "Links and impacts: the influence of public research on industrial R\&D," Management Science, vol. 48, no. 1, pp. 1-23, 2002.

[42] A. Salter, P. Criscuolo, and A. L. Ter Wal, "Coping with Open Innovation: Responding to the Challenges of External Engagement in R\&D," California Management Review, vol. 56, no. 2, 2014 .

[43] W. M. Cohen and D. A. Levinthal, "Absorptive capacity: A new perspective on learning and innovation," Administrative Science Quarterly, vol. 35, no. 1, pp. 128-152, 1990.

[44] A. K. Zobel, "Benefiting from open innovation: a multidimensional model of absorptive capacity," Journal of Product Innovation Management, vol. 34, no. 3, pp. 269-288, 2017.

[45] B. Nooteboom, W. Van Haverbeke, G. Duysters, V. Gilsing, and A. Van den Oord, "Optimal cognitive distance and absorptive capacity," Research Policy, vol. 36, no. 7, pp. 1016-1034, 2007.

[46] U. Lichtenthaler and E. Lichtenthaler, "A Capability-Based Framework for Open Innovation: Complementing Absorptive Capacity," Journal of Management Studies, vol. 46, no. 8, pp. 1315-1338, 2009.

[47] B. Heiman and J. A. Nickerson, "Towards reconciling transaction cost economics and the knowledge-based view of the firm: The context of interfirm collaborations," International Journal of the Economics of Business, vol. 9, no. 1, pp. 97-116, 2002.

[48] W. Vanhaverbeke, Managing Open Innovation in SMEs: Cambridge University Press, 2017.

[49] N. Kumar, L. W. Stern, and J. C. Anderson, "Conducting interorganizational research using key informants," Academy of Management Journal, vol. 36, no. 6, pp. 1633-1651, 1993. 
[50] L. t. Hu and P. M. Bentler, "Cutoff criteria for fit indexes in covariance structure analysis: Conventional criteria versus new alternatives," Structural Equation Modeling: A Multidisciplinary Journal, vol. 6, no. 1, pp. 1-55, 1999.

[51] C. Fornell and D. Larcker, "Evaluating structural equation models with unobservable variables and measurement error," Journal of Marketing Research, vol. 18, no. 1, pp. 39-50, 1981.

[52] J. C. Nunnally and I. Bernstein, "The assessment of reliability," Psychometric Theory, vol. 3, pp. 248-292, 1994.

[53] L. J. Kirsch, "The management of complex tasks in organizations: Controlling the systems development process," Organization Science, vol. 7, no, 1, pp. 1-21, 1996.

[54] J. F. Hair, R. E. Anderson, R. L. Tatham, and W. C. Black, "Multivariate analysis," Englewood: Prentice Hall International, 1998.

[55] G. Punj and D. W. Stewart, "Cluster analysis in marketing research: review and suggestions for application," Journal of Marketing Research, vol. 20, no, 2, pp. 134-148, 1983.

[56] D. J. Ketchen and C. L. Shook, "The application of cluster analysis in strategic management research: an analysis and critique," Strategic Management Journal, vol. 17, no. 6, pp. 441458, 1996.

[57] D. Faems, B. Van Looy, and K. Debackere, "Interorganizational collaboration and innovation: Toward a portfolio approach," Journal of Product Innovation Management, vol. 22, no. 3, pp. 238-250, 2005.

[58] N. Ind, O. Iglesias, and S. Markovic, "The co-creation continuum: from tactical market research tool to strategic collaborative innovation method," Journal of Brand Management, vol. 24, no.4, pp. 1-12, 2017.

[59] S. Brunswicker and W. Vanhaverbeke, "Open innovation in small and medium-sized enterprises (SMEs): External knowledge sourcing strategies and internal organizational facilitators," Journal of Small Business Management, vol. 53, no. 4, pp. 1241-1263, 2015. 
[60] Q. Chen and Z. Liu, "How does openness to innovation drive organizational ambidexterity? The mediating role of organizational learning goal orientation," IEEE Transactions on Engineering Management, vol. 66, no., 2, pp. 156-169, 2018.

[61] E. Enkel, O. Gassmann, and H. Chesbrough, "Open R\&D and open innovation: exploring the phenomenon," R\&d Management, vol. 39, no. 4, pp. 311-316, 2009.

[62] W. Chang and S. A. Taylor, "The effectiveness of customer participation in new product development: A meta-analysis," Journal of Marketing, vol. 80, no. 1, pp. 47-64, 2016.

[63] J. Hagedoorn, B. Lokshin, and A. K. Zobel, "Partner Type Diversity in Alliance Portfolios: Multiple Dimensions, Boundary Conditions and Firm Innovation Performance," Journal of Management Studies, vol. 55, no. 5, pp. 809-836, 2018.

[64] J. Penin and T. Burger-Helmchen, "Crowdsourcing of inventive activities: definition and limits," International Journal of Innovation and Sustainable Development, vol. 5, no. 2, pp. 246-263, 2011.

[65] B. L. Bayus, "Crowdsourcing new product ideas over time: An analysis of the Dell IdeaStorm community," Management Science, vol. 59, no. 1, pp. 226-244, 2013.

[66] P. Pollok, D. Lüttgens, and F. T. Piller, "Attracting solutions in crowdsourcing contests: The role of knowledge distance, identity disclosure, and seeker status," Research Policy, vol. 48, no. 1, pp. 98-114, 2019.

[67] R. C. Ford, B. Richard, and M. P. Ciuchta, "Crowdsourcing: A new way of employing nonemployees?," Business Horizons, vol. 58, no. 4, pp. 377-388, 2015.

[68] F. Cappa, R. Oriani, M. Pinelli, and A. De Massis, "When does crowdsourcing benefit firm stock market performance?," Research Policy, vol. 48, no. 9, 2019. https://doi.org/10.1016/j.respol.2019.103825

[69] E. Segev, "Crowdsourcing contests," European Journal of Operational Research, 2019. https://doi.org/10.1016/j.ejor.2019.02.057 
[70] A. Ghezzi, D. Gabelloni, A. Martini, and A. Natalicchio, "Crowdsourcing: a review and suggestions for future research," International Journal of Management Reviews, vol. 20, no. 2, pp. 343-363, 2018.

[71] M. Piazza, E. Mazzola, N. Acur, and G. Perrone, "Governance Considerations for SeekerSolver Relationships: A Knowledge-Based Perspective in Crowdsourcing for Innovation Contests," British Journal of Management, 2019. https://doi.org/10.1111/1467-8551.12327

[72] C. K. Prahalad and V. Ramaswamy, "Co-creation experiences: The next practice in value creation," Journal of Interactive Marketing, vol. 18, no. 3, pp. 5-14, 2004.

[73] M. Bianchi, A. Cavaliere, D. Chiaroni, F. Frattini, and V. Chiesa, "Organisational modes for Open Innovation in the bio-pharmaceutical industry: An exploratory analysis," Technovation, vol. 31, no. 1, pp. 22-33, 2011.

[74] D. Chiaroni, V. Chiesa, and F. Frattini, "Investigating the adoption of open innovation in the bio-pharmaceutical industry: a framework and an empirical analysis," European Journal of Innovation Management, vol. 12, no. 3, pp. 285-305, 2009.

[75] P. S. Ring and A. H. Van de Ven, "Developmental processes of cooperative interorganizational relationships," Academy of Management Review, vol. 19, no. 1, pp. 90118, 1994.

[76] G. Arcese, S. Flammini, M. Lucchetti, and O. Martucci, "Evidence and experience of open sustainability innovation practices in the food sector," Sustainability, vol. 7, no. 7, pp. 80678090, 2015.

[77] F. Cappa, F. Del Sette, D. Hayes, and F. Rosso, "How to deliver open sustainable innovation: An integrated approach for a sustainable marketable product," Sustainability, vol. 8, no. 12, p. 1341-, 2016.

[78] S. Kuhlmann and A. Rip, "Next-generation innovation policy and grand challenges," Science and Public Policy, vol. 45, no, 4, pp. 448-454, 2018.

[79] R. K. Yin, Qualitative research from start to finish: Guilford Publications, 2015. 
[80] A. Abbott and A. Tsay, "Sequence analysis and optimal matching methods in sociology: Review and prospect," Sociological Methods \& Research, vol. 29, no. 1, pp. 3-33, 2000.

[81] A. Abbott, "A primer on sequence methods," Organization Science, vol. 1, no. 4, pp. 375392, 1990.

[82] P. C. Fiss, "A set-theoretic approach to organizational configurations," Academy of Management Review, vol. 32, no. 4, pp. 1180-1198, 2007.

[83] A. Marx, B. Rihoux, and C. Ragin, "The origins, development, and application of Qualitative Comparative Analysis: the first 25 years," European Political Science Review, vol. 6, no. 1, pp. 115-142, 2014.

[84] S. W. Raudenbush and A. S. Bryk, Hierarchical linear models: Applications and data analysis methods vol. 1: Sage, 2002. 


\section{TABLES AND FIGURES}

Table 1. Sample characteristics

\begin{tabular}{|lr|lr|}
\hline Industry & $\%$ & Firm's total revenue in 2015 (USD) & $\%$ \\
\hline Finance, Banking, and Insurance & 24.4 & \$11 million-\$100 million & 23.4 \\
Health Care and Social Assistance & 13.4 & \$101 million-\$500 million & 18 \\
Manufacturing & 33.3 & \$501 million-\$1 billion & 11.8 \\
Retail/Wholesale Trade & 28.9 & \$1 billion-\$5 billion & 25.9 \\
& & Over \$5 billion & 20.9 \\
\hline Number of employees & & Respondent job position/role & 15.9 \\
\hline 500 - 999 employees & 15.4 & Owner / CEO & 27.9 \\
1000 - 4999 employees & 38.8 & Senior executive & 10.4 \\
5000 -7499 employees & 11.9 & Executive & 20.9 \\
7500 - 9999 employee & 8 & Senior Manager & 24.9 \\
10000 employees or more & 25.9 & Manager or supervisor & \\
\hline
\end{tabular}

Table 2. Correlation coefficients between the two project attributes and managerial factors

\begin{tabular}{|l|c|c|c|c|c|c|}
\hline & $\begin{array}{c}\text { Openness } \\
\text { breadth }\end{array}$ & $\begin{array}{c}\text { Openness } \\
\text { depth }\end{array}$ & $\begin{array}{c}\text { Diversity of } \\
\text { mechanisms }\end{array}$ & $\begin{array}{c}\text { Collaboration } \\
\text { process } \\
\text { formalization }\end{array}$ & $\begin{array}{c}\text { Knowledge } \\
\text { incentives }\end{array}$ & $\begin{array}{c}\text { Internal } \\
\text { communication }\end{array}$ \\
\hline Project & 0.264 & 0.204 & 0.149 & 0.441 & 0.505 & 0.431 \\
complexity & $(<0.001)$ & $(0.004)$ & $(0.036)$ & $(<0.001)$ & $(<0.001)$ & $(<0.001)$ \\
\hline Project & 0.229 & 0.137 & 0.131 & 0.481 & 0.472 & 0.570 \\
uncertainty & $(0.001)$ & $(0.052)$ & $(0.065)$ & $(<0.001)$ & $(<0.001)$ & $(<0.001)$ \\
\hline
\end{tabular}

Pearson correlation coefficient; $p$-value is reported in parentheses.

Table 3. Means of managerial factors for different levels of project complexity

\begin{tabular}{|c|c|c|c|c|c|c|}
\hline 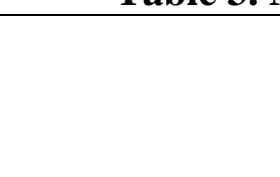 & $\begin{array}{l}\text { Low project } \\
\text { complexity } \\
\left(1^{\text {st }} Q\right)\end{array}$ & $2^{\text {nd }} Q$ & $3^{\text {rd }} Q$ & $\begin{array}{l}\text { High project } \\
\text { complexity } \\
\text { (Last Q) }\end{array}$ & $\begin{array}{l}\text { ANOVA } \\
\text { F-value } \\
(\mathrm{df}=3)\end{array}$ & t-test \\
\hline $\begin{array}{l}\text { Openness } \\
\text { breadth }\end{array}$ & 4 & 3.94 & 4.4 & 4.7 & $5.602^{* *}$ & $\begin{array}{l}\text { Last } \mathrm{Q}>2^{\text {nd } \mathrm{d}^{* *}}, 1^{\mathrm{st} * * *} \\
\qquad 3^{\mathrm{rd}}>2^{\text {nd+ }}, 1^{\mathrm{st}+}\end{array}$ \\
\hline $\begin{array}{l}\text { Openness } \\
\text { depth }\end{array}$ & 1.7 & 1.89 & 2.13 & 2.12 & $4.289^{* *}$ & Last $\mathrm{Q}, 3^{\mathrm{rd}}>1^{\mathrm{s} \mathrm{s}^{* *}}$ \\
\hline $\begin{array}{l}\text { Diversity of } \\
\text { mechanisms }\end{array}$ & 2.05 & 1.91 & 2.53 & 2.27 & $2.476^{+}$ & $3^{\mathrm{rd}}>2^{\mathrm{nd} *}, 1^{\mathrm{st}^{*}}$ \\
\hline $\begin{array}{l}\text { Collaboration } \\
\text { process } \\
\text { formalization }\end{array}$ & 5.4 & 5.7 & 6.03 & 6.36 & $20.123^{* * *}$ & $\begin{array}{c}\text { Last } Q>3^{\text {rd } *}, 2^{\text {nd } * * *}, 1^{\mathrm{st***}} \\
3^{\text {rd }}>2^{\text {nd+ }}, 1^{\text {st*** }} \\
2^{\text {nd }}>1^{\text {st+ }}\end{array}$ \\
\hline $\begin{array}{l}\text { Knowledge } \\
\text { incentives }\end{array}$ & 4.4 & 5 & 5.78 & 6.11 & $21.100^{* * * *}$ & $\begin{array}{c}\text { Last } \mathrm{Q}>2^{\text {nd } * *}, 1^{\mathrm{st***}} \\
3^{\text {rd }}>2^{\text {nd } d^{*}}, 1^{\text {st***}^{* *}} \\
2^{\text {nd }}>1^{\text {st+ }}\end{array}$ \\
\hline $\begin{array}{l}\text { Internal } \\
\text { communication }\end{array}$ & 5.61 & 5.86 & 6.18 & 6.41 & $11.031^{* * * *}$ & $\begin{array}{c}\text { Last } \mathrm{Q}>3^{\text {rd }+}, 2^{\text {nd } * *}, 1^{\text {st *** }} \\
3^{\text {rd }}>2^{\text {nd }+}, 1^{\text {st** }}\end{array}$ \\
\hline
\end{tabular}


Table 4. Means of managerial factors for different levels of project uncertainty

\begin{tabular}{|c|c|c|c|c|c|c|}
\hline (2) & $\begin{array}{l}\text { Low project } \\
\text { uncertainty } \\
\left(1^{\text {st }} Q\right)\end{array}$ & $2^{\text {nd }} Q$ & $3^{\text {rd }} Q$ & $\begin{array}{l}\text { High project } \\
\text { uncertainty } \\
\text { (Last Q) }\end{array}$ & $\begin{array}{l}\text { ANOVA } \\
\text { F-value } \\
(\mathrm{df}=3)\end{array}$ & \\
\hline $\begin{array}{l}\text { Openness } \\
\text { breadth }\end{array}$ & 3.91 & 4.09 & 4.41 & 4.56 & $4.059^{* *}$ & $\begin{array}{l}\text { Last } \mathrm{Q}>2^{\mathrm{nd}+}, 1^{\mathrm{st**}} \\
3^{\mathrm{rd}}>1^{\mathrm{st} *}\end{array}$ \\
\hline $\begin{array}{l}\text { Openness } \\
\text { depth }\end{array}$ & 1.79 & 1.81 & 1.99 & 2.09 & 1.969 & Last $\mathrm{Q}>2^{\mathrm{nd}+}, 1^{\mathrm{st}}$ \\
\hline $\begin{array}{l}\text { Diversity of } \\
\text { mechanisms }\end{array}$ & 2.12 & 1.88 & 2.3 & 2.31 & 1.375 & $\begin{array}{c}\text { Last } Q>2^{\text {nd* }} \\
3^{\text {rd }}>2^{\text {nd+ }}\end{array}$ \\
\hline $\begin{array}{l}\text { Collaboration } \\
\text { process } \\
\text { formalization }\end{array}$ & 5.28 & 5.54 & 6.04 & 6.33 & $27.241^{\text {*** }}$ & $\begin{array}{c}\text { Last } \mathrm{Q}>3^{\text {rd } *}, 2^{\text {nd } * * *}, 1^{\mathrm{st} * * *} \\
3^{\text {rd }}>2^{\text {nd }}, 1^{\mathrm{st}^{* * * *}}\end{array}$ \\
\hline $\begin{array}{l}\text { Knowledge } \\
\text { incentives }\end{array}$ & 4.38 & 4.91 & 5.43 & 6.06 & $17.740^{* * * *}$ & $\begin{array}{c}\text { Last } \mathrm{Q}>3^{\mathrm{rd} *}, 2^{\text {nd } * * *}, 1^{\mathrm{st} * * *} \\
3^{\mathrm{rd}}>1^{\mathrm{st} * * *} \\
2^{\text {nd }}>1^{\mathrm{st}+}\end{array}$ \\
\hline $\begin{array}{l}\text { Internal } \\
\text { communication }\end{array}$ & 5.3 & 5.97 & 6.19 & 6.42 & $23.129^{* * *}$ & $\begin{array}{c}\text { Last } \mathrm{Q}>3^{\mathrm{rd}+}, 2^{\text {nd } * *}, 1^{\mathrm{st} * *} \\
3^{\text {rd }} ; 2^{\text {nd }}>1^{\mathrm{s} * * *}\end{array}$ \\
\hline
\end{tabular}

Table 5. Means of time spent with different external partners for four clusters of projects

\begin{tabular}{|c|c|c|c|c|c|c|}
\hline $\begin{array}{l}\text { External } \\
\text { partners }\end{array}$ & $\begin{array}{l}\text { Cluster } 1 \\
(\mathrm{n}=41)\end{array}$ & $\begin{array}{l}\text { Cluster } 2 \\
(\mathrm{n}=58)\end{array}$ & $\begin{array}{l}\text { Cluster } 3 \\
(\mathrm{n}=43)\end{array}$ & $\begin{array}{c}\text { Cluster } 4 \\
(\mathrm{n}=59)\end{array}$ & $\begin{array}{l}\text { ANOVA } \\
\text { F-value } \\
(\mathrm{df}=3)\end{array}$ & t-test \\
\hline Competitors & 3.88 & 2.78 & 2.19 & 1.63 & $79.189^{* *}$ & $1>2^{* *}>3^{* *}>4^{* *}$ \\
\hline $\begin{array}{l}\text { Universities } \\
\text { and public } \\
\text { research } \\
\text { organizations }\end{array}$ & 3.83 & 2.76 & 2.00 & 1.39 & $94.088^{* *}$ & $1>2^{* *}>3^{* *}>4^{* *}$ \\
\hline $\begin{array}{l}\text { Entrepreneurs } \\
\text { and start-ups }\end{array}$ & 4.15 & 2.86 & 2.40 & 1.59 & $98.672^{* *}$ & $\begin{array}{c}1>2^{* *}, 3^{* *}>4^{* *} \\
2>3^{*}\end{array}$ \\
\hline Users & 4.10 & 2.45 & 4.05 & 2.31 & $84.005^{* *}$ & $1,3>2^{* *}, 4^{* *}$ \\
\hline Suppliers & 4.15 & 2.43 & 3.26 & 2.00 & $83.248^{* *}$ & $\begin{array}{c}1>2^{* *}, 3^{* *}, 4^{* *} \\
3>2^{* *}, 4^{* *} \\
2>4^{*}\end{array}$ \\
\hline
\end{tabular}

$\mathrm{n}=$ Number of projects in each cluster; $\mathrm{df}=$ degree of freedom; ${ }^{*}=\mathrm{p}<0.01 ;{ }^{* *}=\mathrm{p}<0.001$ 
Table 6. Cross-tabulation of the two project attributes and external partner choice

\begin{tabular}{|c|c|c|c|c|c|}
\hline & \multicolumn{4}{|c|}{ External partner choice } \\
\hline & & Cluster 1 & Cluster 2 & Cluster 3 & Cluster 4 \\
\hline \multirow{4}{*}{$\begin{array}{l}\text { Project } \\
\text { complexity }\end{array}$} & \multirow{2}{*}{ High } & Obs. 20 & Obs. 20 & Obs. 10 & Obs. 10 \\
\hline & & Exp. 11 & Exp. 17.6 & Exp. 12.4 & Exp. 19 \\
\hline & \multirow{2}{*}{ Low } & Obs. 3 & Obs. 17 & Obs. 16 & Obs. 30 \\
\hline & & Exp. 12 & Exp. 19.4 & Exp. 13.6 & Exp. 21 \\
\hline \multicolumn{6}{|c|}{ Chi-square $=23.962, \mathrm{df}=3, \mathrm{p}<0.001$} \\
\hline \multirow{4}{*}{$\begin{array}{l}\text { Project } \\
\text { uncertainty }\end{array}$} & \multirow{2}{*}{ High } & Obs. 21 & Obs. 23 & Obs. 16 & Obs. 11 \\
\hline & & Exp. 15.5 & Exp. 21.2 & Exp. 15.5 & Exp. 18.9 \\
\hline & \multirow{2}{*}{ Low } & Obs. 6 & Obs. 14 & Obs. 11 & Obs. 22 \\
\hline & & Exp. 11.5 & Exp. 15.8 & Exp. 11.5 & Exp. 14.1 \\
\hline
\end{tabular}

Obs. = Observed frequency of projects; Exp. = Expected frequency of projects; $\mathrm{df}=$ degree of freedom

Table 7. Means of project complexity and uncertainty for four clusters of projects

\begin{tabular}{|l|c|c|c|c|c|c|}
\hline $\begin{array}{l}\text { External } \\
\text { partners }\end{array}$ & Cluster 1 & Cluster 2 & Cluster 3 & Cluster 4 & $\begin{array}{c}\text { ANOVA } \\
\text { F-value } \\
(\mathrm{df}=3)\end{array}$ & t-test \\
\hline $\begin{array}{l}\text { Project } \\
\text { complexity }\end{array}$ & 6.18 & 5.71 & 5.63 & 5.23 & $9.182^{* * *}$ & $\begin{array}{c}1>2^{* *}, 3^{* *}, 4^{* * *} \\
2,3>4^{*}\end{array}$ \\
\hline $\begin{array}{l}\text { Project } \\
\text { uncertainty }\end{array}$ & 6.16 & 5.73 & 5.85 & 5.47 & $4.164^{* *}$ & $\begin{array}{c}1>2^{*}, 3^{+}, 4^{* * *} \\
3>4^{*}\end{array}$ \\
\hline
\end{tabular}

$\mathrm{df}=$ degree of freedom ${ }^{+}=\mathrm{p}<0.1 ;^{*}=\mathrm{p}<0.05 ;^{* *}=\mathrm{p}<0.01 ;^{* * *}=\mathrm{p}<0.001$

Table 8. Means of project complexity and uncertainty for different OI mechanisms

\begin{tabular}{|c|c|c|c|c|c|c|c|c|}
\hline & \multicolumn{2}{|c|}{$\begin{array}{l}\text { Bilateral } \\
\text { contracts }\end{array}$} & \multicolumn{2}{|c|}{$\begin{array}{l}\text { Collaborative } \\
\text { agreements }\end{array}$} & \multicolumn{2}{|c|}{$\begin{array}{l}\text { Innovation } \\
\text { contests or } \\
\text { crowdsourcing } \\
\text { intermediaries }\end{array}$} & \multicolumn{2}{|c|}{$\begin{array}{c}\text { Corporate } \\
\text { innovation } \\
\text { communities }\end{array}$} \\
\hline & $\mathrm{A}$ & NA & $\mathrm{A}$ & NA & $\mathrm{A}$ & NA & $\mathrm{A}$ & NA \\
\hline \multirow{2}{*}{$\begin{array}{l}\text { Project } \\
\text { complexity }\end{array}$} & 5.75 & 5.57 & 5.63 & 5.7 & 5.76 & 5.49 & 5.78 & 5.54 \\
\hline & \multicolumn{2}{|c|}{$\begin{array}{l}\mathrm{t} \text {-value }=-1.369 \\
\mathrm{p} \text {-value }=0.173\end{array}$} & \multicolumn{2}{|c|}{$\begin{aligned} \mathrm{t} \text {-value } & =0.519 \\
\mathrm{p} \text {-value } & =0.605\end{aligned}$} & \multicolumn{2}{|c|}{$\begin{array}{l}t \text {-value }=-2.042 \\
p \text {-value }=0.043\end{array}$} & \multicolumn{2}{|c|}{$\begin{array}{c}\mathrm{t} \text {-value }=-1.825 \\
\mathrm{p} \text {-value }=0.07\end{array}$} \\
\hline \multirow[t]{2}{*}{$\begin{array}{l}\text { Project } \\
\text { uncertainty }\end{array}$} & 5.81 & 5.74 & 5.72 & 5.84 & 5.89 & 5.59 & 5.94 & 5.6 \\
\hline & \multicolumn{2}{|c|}{$\begin{array}{l}\text { t-value }=-0.475 \\
p \text {-value }=0.635\end{array}$} & \multicolumn{2}{|c|}{$\begin{aligned} \mathrm{t} \text {-value } & =0.835 \\
\mathrm{p} \text {-value } & =0.405\end{aligned}$} & \multicolumn{2}{|c|}{$\begin{array}{l}\mathrm{t} \text {-value }=-2.105 \\
\mathrm{p} \text {-value }=0.037\end{array}$} & \multicolumn{2}{|c|}{$\begin{array}{l}\mathrm{t} \text {-value }=-2.416 \\
\mathrm{p} \text {-value }=0.017\end{array}$} \\
\hline
\end{tabular}

$\mathrm{A}=$ Applied; NA $=$ Not Applied 
Fig. 1. Means of project openness level for high and low levels of project complexity and uncertainty

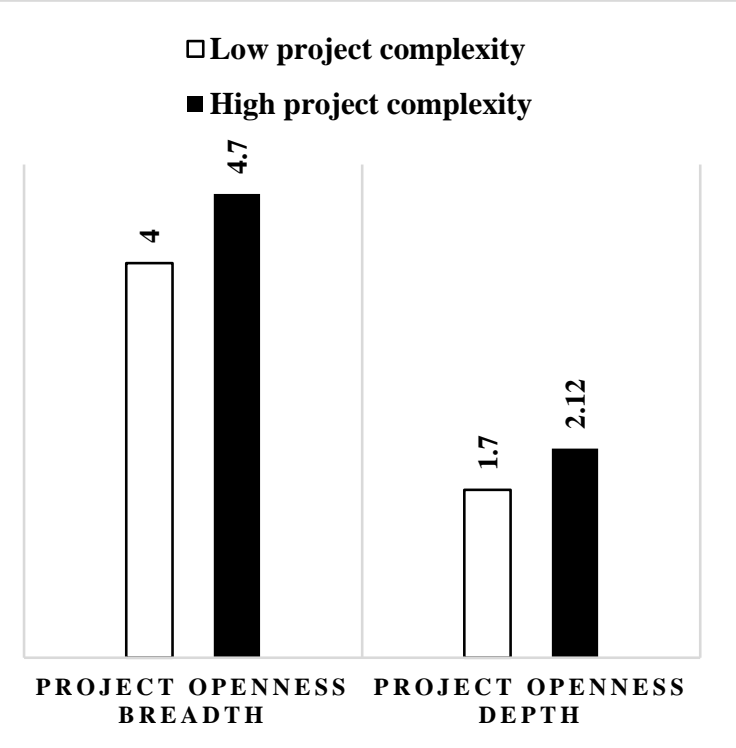

$\mathrm{t}$-value $=-3.704$

p-value $<0.001$ $\mathrm{t}$-value $=-3.185$

p-value $=0.002$

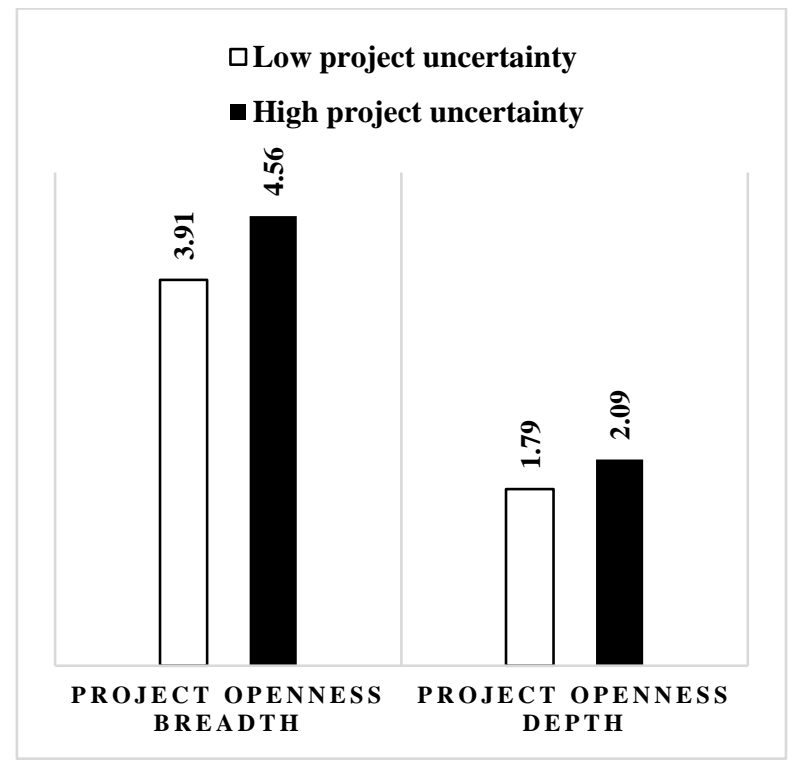

$\mathrm{t}-$ value $=-3.060$

$\mathrm{t}$-value $=-2.181$

$\mathrm{p}$-value $=0.003$

Fig. 2. Interaction effect between the two project attributes on project openness level
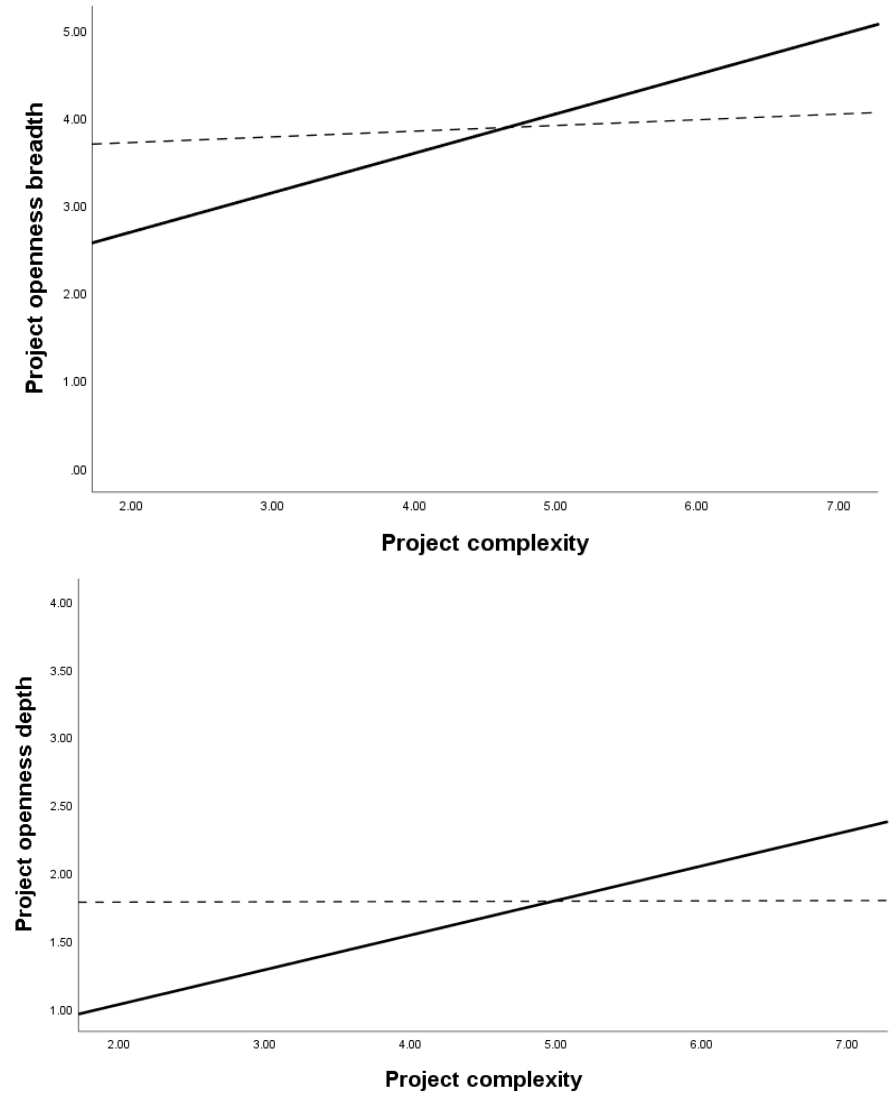

Project uncertainty

Low

High 
Fig. 3. Percentage of projects applying different OI mechanisms

Bilateral contracts

Corporate innovation communities

collaborative agreement with external partners

Innovation Contests/crowdsouring intermediaries

Fig. 4. Percentage of projects for diversity of OI mechanisms applied

Four OI mechanisms

Three OI mechanisms

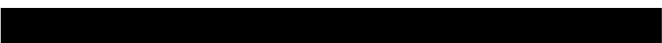

$22.50 \%$

Two OI mechanisms

One OI mechanism

$30 \%$

Fig. 5. Means of collaboration process formalization for high and low project complexity and uncertainty

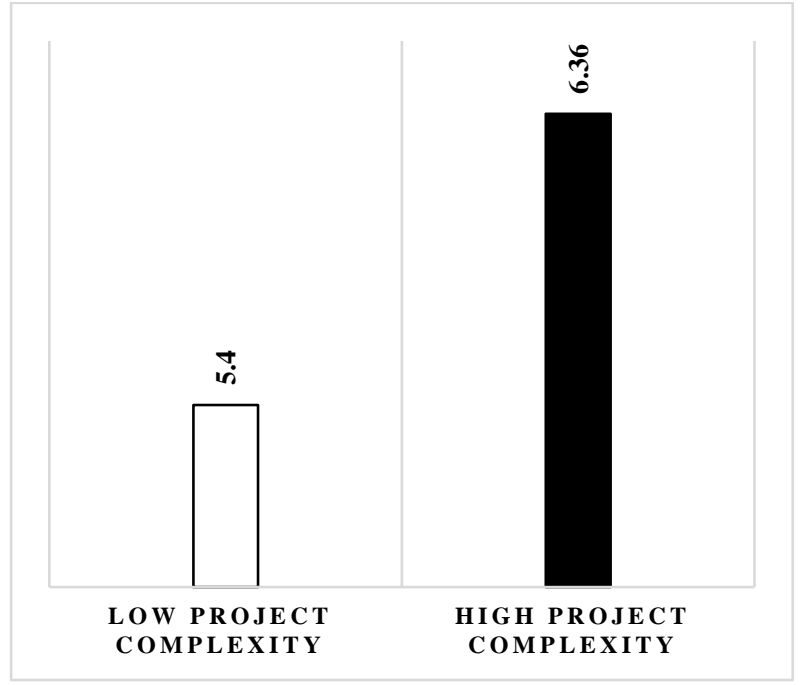

$\mathrm{t}$-value $=-7.856$

$\mathrm{p}$-value $<0.001$

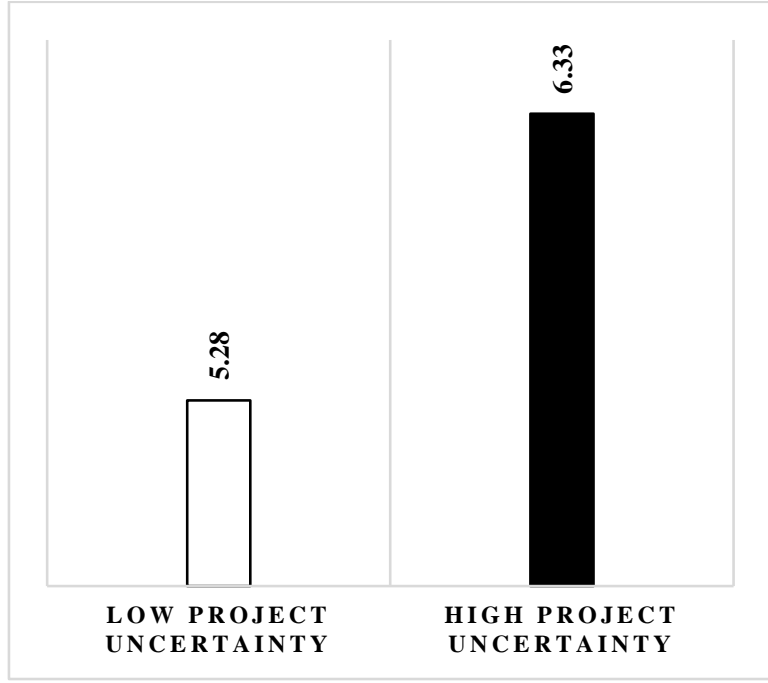

$\mathrm{t}$-value $=-8.095$

p-value $<0.001$ 
Fig. 6. Means of internal firm practices for high and low project complexity and uncertainty
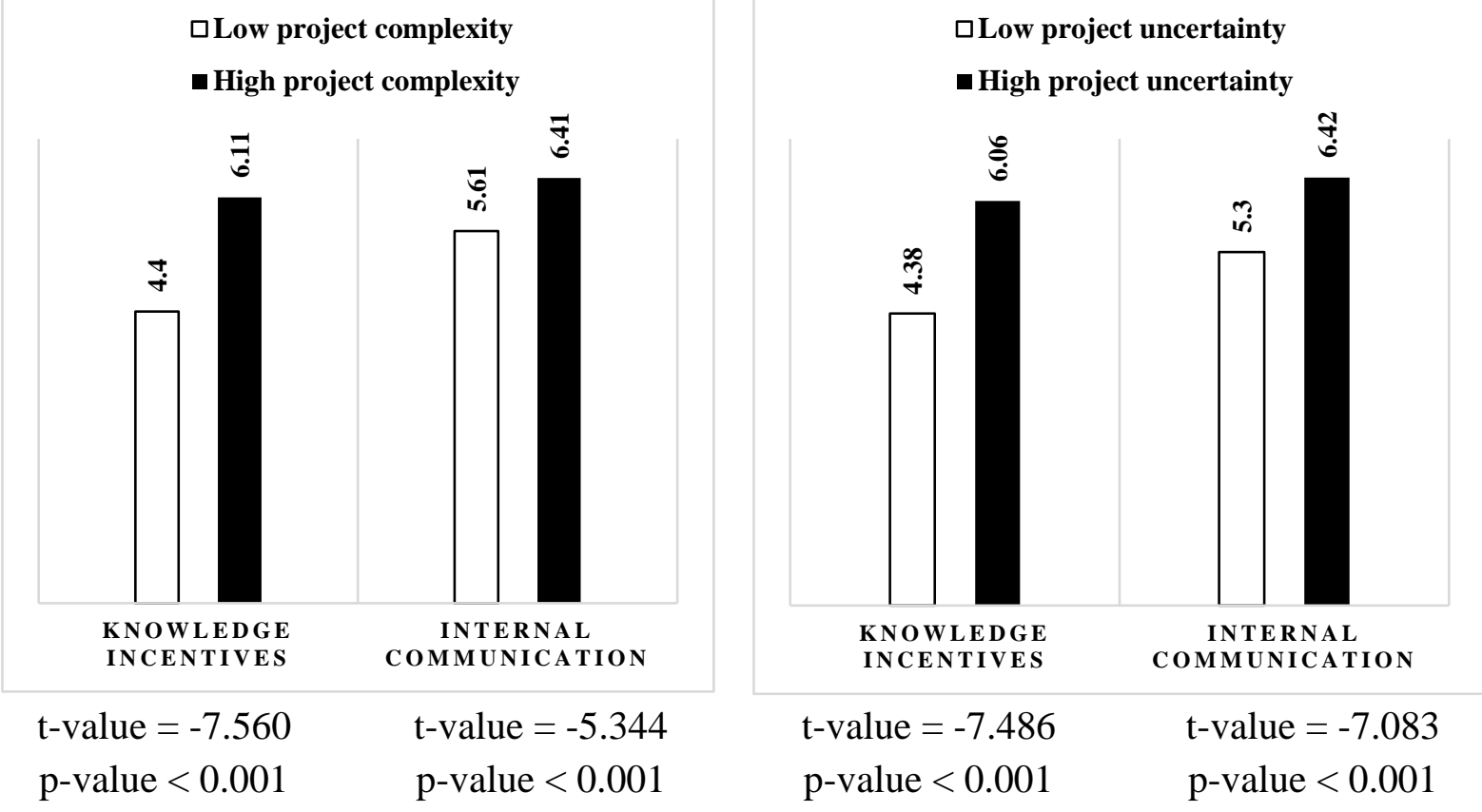

\section{APPENDIX}

Means of managerial factors for different levels of project complexity and uncertainty

\begin{tabular}{|l|c|c|c|c|c|c|}
\hline & \multicolumn{3}{|c|}{ Project complexity } & \multicolumn{3}{c|}{ Project uncertainty } \\
\hline & $1^{\text {st }}$ and $2^{\text {nd }} \mathrm{Q}$ & $3^{\text {rd }}$ and Last Q & $\mathrm{p}$-value & $1^{\text {st }}$ and $2^{\text {nd }} \mathrm{Q}$ & $3^{\text {rd }}$ and Last Q & $\mathrm{p}$-value \\
\hline $\begin{array}{l}\text { Openness } \\
\text { breadth }\end{array}$ & 3.98 & 4.58 & $<0.001$ & 4.12 & 4.56 & 0.004 \\
\hline Openness depth & 1.77 & 2.12 & 0.001 & 1.87 & 2.09 & 0.047 \\
\hline $\begin{array}{l}\text { Diversity of } \\
\text { mechanisms }\end{array}$ & 2 & 2.37 & 0.017 & 2.12 & 2.31 & 0.24 \\
\hline $\begin{array}{l}\text { Collaboration } \\
\text { process } \\
\text { formalization }\end{array}$ & 5.5 & 6.22 & $<0.001$ & 5.6 & 6.33 & $<0.001$ \\
\hline $\begin{array}{l}\text { Knowledge } \\
\text { incentives }\end{array}$ & 4.61 & 5.98 & $<0.001$ & 4.87 & 6.06 & $<0.001$ \\
\hline $\begin{array}{l}\text { Internal } \\
\text { communication }\end{array}$ & 5.69 & 6.32 & $<0.001$ & 5.77 & 6.42 & $<0.001$ \\
\hline
\end{tabular}

